\title{
Modeling of seawater intrusion into coastal aquifers in laboratory conditions
}

\author{
Marin Brkić \\ Satira d.o.o., M.Eng.C.E. \\ marin.brkic@gf.sum.ba \\ Veljko Srzić \\ Faculty of Civil Engineering, Architecture, and Geodesy, University of Split, Ph.D C.E. \\ vsrzic@gradst.hr
}

\begin{abstract}
The impact of groundwater level reduction plays an important role in the intrusion of seawater in coastal aquifers. Seawater intrusion is becoming the main constraint on the use of fresh groundwater in coastal aquifers. The aim of this study is to establish the simulation model of the seawater intrusion process in a porous coastal aquifer and to generate data sets for describing the intrusion of a saltwater wedge in a porous medium as a function of time. The experiment was performed with one porous medium of a certain porosity and with a constant hydraulic gradient. The experiment showed that the largest intrusion of the salt wedge was at the very beginning of the experiment and that the mixing zone of fresh and salt water was insignificant. Over time the changes of the salt wedge become insignificant and the salt wedge reached a steady state condition. The results of this experiment will help in future planning to solve the problem of salt water intrusion into coastal aquifers.
\end{abstract}

Key words: seawater intrusion, laboratory experiment, saltwater wedge, coastal aquifer, groundwater

\section{Modeliranje intruzije morske vode u obalni vodonosnik u laboratorijskim uvjetima}

Sažetak: Utjecaj smanjenja razine podzemne vode igra važnu ulogu u intruziji morske vode u obalne vodonosnike. Intruzija morske vode postaje glavno ograničenje za korištenje slatke podzemne vode u obalnim vodonosnicima. Cilj ovoga rada je laboratorijskim eksperimentom uspostaviti model simulacije procesa intruzije morske vode u poroznom obalnom vodonosniku, te generirati skupove podataka za opisivanje intruzije slanog klina u poroznom mediju u ovisnosti o vremenu. Eksperiment je odrađen s jednim poroznim medijem određene poroznosti i sa stalnim hidrauličkim gradijentom. Eksperiment je pokazao da je najveća intruzija slanoga klina na samome početku eksperimenta, te da je miješanje slatke i slane vode neznatno. Vremenom promjene slanog klina postaju neznatne i klin doseže stanje ravnoteže. Rezultati ovoga eksperimenta će pomoći u budućem planiranju rješavanja problema intruzije slane vode u obalne vodonosnike.

Ključne riječi: intruzija morske vode, laboratorijski eksperiment, klin slane vode, obalni vodonosnik, podzemna voda 
Brkić, M., Srzić, V.

Modeling of seawater intrusion into coastal aquifers in laboratory conditions

\section{INTRODUCTION}

Seawater intrusion is often the main constraint on the use of fresh groundwater in coastal aquifers. Overuse of groundwater, as a response to the deteriorating state of the quantity and quality of available surface water, has caused groundwater levels to decline. Together with continued sea level rise due to global warming, coastal aquifers are under even greater threat. About $70 \%$ of the world's population lives in coastal areas [1]. Excessive groundwater exploitation resulted in seawater intrusion into Laizhou Bay, China [2]. The salinity of many groundwater samples is higher than $1000 \mathrm{mg} / \mathrm{L}$ in an area up to ten kilometers inland from the coast [3]. The seawater intrusion affected an area of $700 \mathrm{~km}^{2}$, and caused great damage to the local agricultural industry [3]. Managing the intrusion of saltwater into coastal aquifers is one of the most challenging environmental management problems in the world [4]. Scientists have focused on the mechanism itself, the mathematical model, and on solving, predicting, and preventing seawater intrusion [5].

Mathematical solutions and numerical methods for solving seawater intrusion have been applied [6]. Harold Henry considered the saltwater intrusion into confined aquifers as a problem and developed an analytical solution in his doctoral dissertation. Henry studied the problem of salt wedge transport in a rectangular, saturated, two-dimensional, and confined porous medium domain [7]. Henry's analytical expression indicated certain errors and appropriate corrections were proposed. These corrections made it possible to match the numerical results of future investigators with Henry's solutions [8]. Ketabchi et al. used analytical solutions by analyzing groundwater on two-layer islands under the influence of increasing seawater levels [9]. Shi et al. assessed the impact of equilibrium seawater intrusion during sea level rise on a stratified coastal aquifer [10]. Applications of analytical methods for estimating seawater position in coastal aquifers requires many assumptions such as the freshwater-seawater transition zone [11].

Numerical methods can show seawater intrusion more realistically in terms of the dispersion effect [11]. Abd-Elhamin and Javadi developed a density-dependent finite element method to study the intrusion of saltwater into coastal aquifers. The variability of saltwater density and dispersion were taken into account in simulation [12]. Mehdizadeh et al. investigated the gradual and immediate effect of seawater rise on seawater intrusion in stratified aquifers using SEAWAT [13]. Sun et al. investigated the influence of inland boundary conditions on salt wedge intrusion in coastal aquifers during sea level rise. Numerical simulation was performed using TOUGH2/EOS7 [14]. Sefelnasr and Sherif investigated the effect of seawater intrusion during the level rise of the Mediterranean Sea in the Nile River Delta using FEFLOW [15].

The researchers also investigated the intrusion of a salt wedge in an aquifer in a laboratory. Goswami and Clement conducted an experiment on the dynamics of saltwater intrusion into a porous medium at different hydraulic gradients [16]. Kuan et al. investigated the tidal influence on the intrusion of a saltwater wedge in a sand flume [17]. Jin $\mathrm{Na}$ et al. studied the influence of seawater density variation through different hydraulic gradients on seawater intrusion in confined coastal aquifers [18].

The objective of this paper is in the laboratory to establish a model that has the capacity to simulate the process of saltwater intrusion in a porous coastal aquifer. An experiment of seawater intrusion in a porous aquifer, which includes preparation activities such as determination of hydraulic permeability, was conducted. The objective of the paper is also to generate time-dependent data sets for describing the intrusion of a saltwater wedge into a porous medium. The main hydrogeological factors influencing the saltwater transport into the coastal aquifer are defined and clearly indicated.

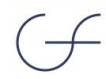


Brkić, M., Srzić, V.

Modeling of seawater intrusion into coastal aquifers in laboratory conditions

\section{PREPARATION OF THE EXPERIMENT}

The experiment was conducted in a rectangular flow tank. The dimensions of the tank are $300 \mathrm{~cm}$ (length), $65 \mathrm{~cm}$ (height) and $12.5 \mathrm{~cm}$ (width). The diagram of the tank itself is shown in Figure 1.

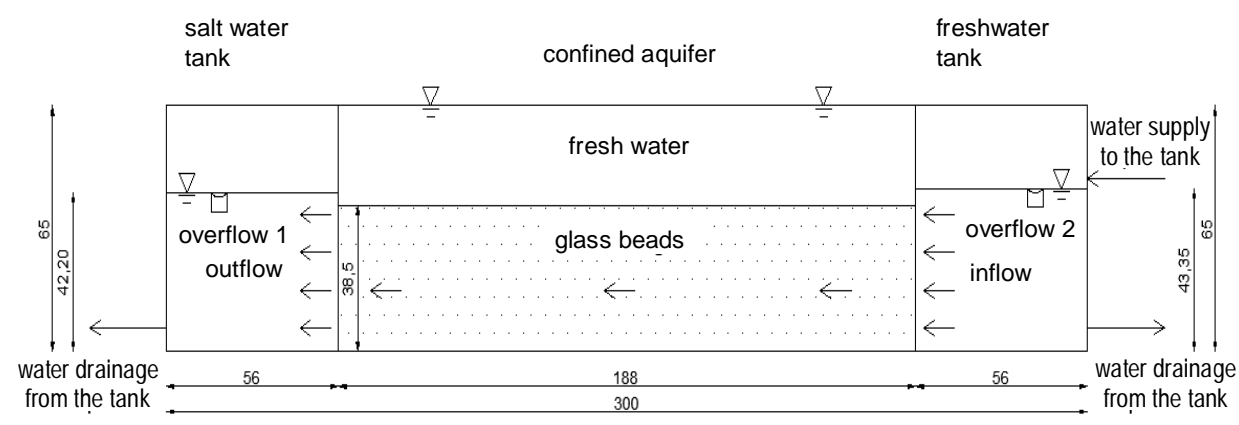

Figure 1. Schematic view of the tank

The tank is made of steel and glass, and consists of three chambers. The model of confined aquifer is located in the middle chamber, which is filled with a porous medium in fully saturated conditions at a height of $38.5 \mathrm{~cm}$ and a length of $188 \mathrm{~cm}$, as shown in Figure 2. A $20 \mathrm{~cm}$ layer of water is above the porous medium, ensuring that the aquifer is under pressure, which is also shown in Figure 2. The constant water level of $20 \mathrm{~cm}$ is ensured by placing water inside a foil.

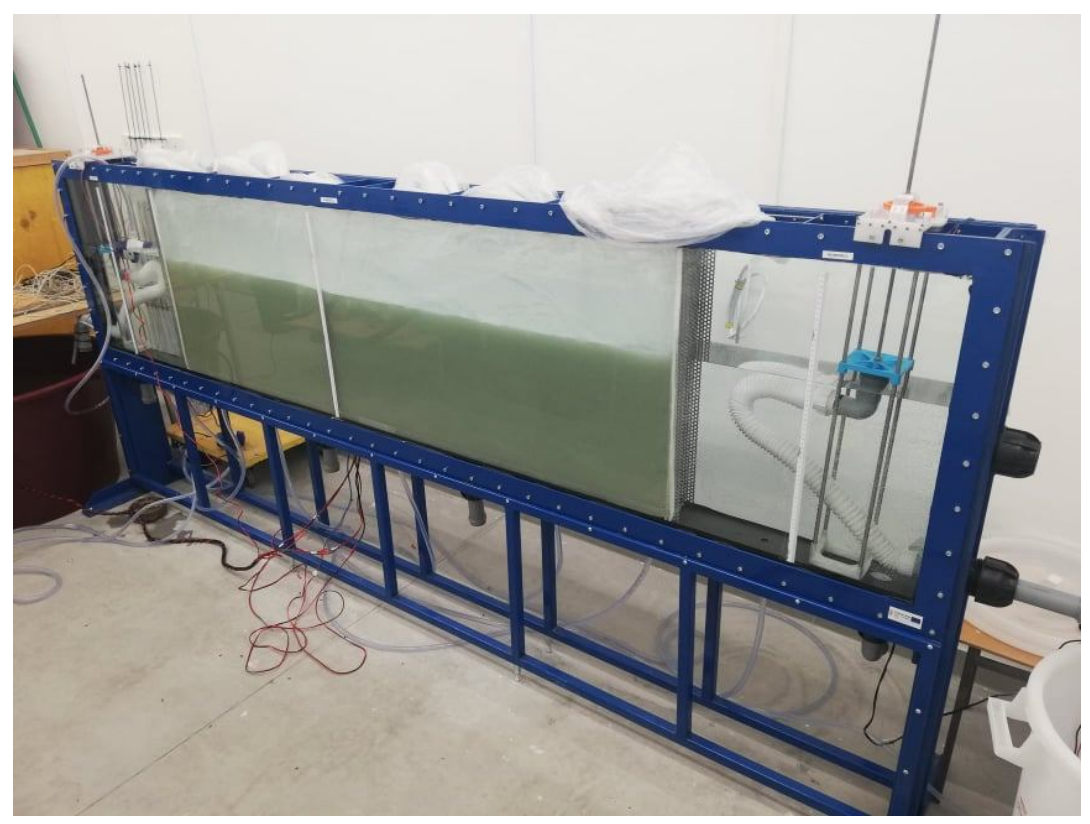

Figure 2. A view of tank components

The porous medium consists of glass beads with diameters from $0.85 \mathrm{~mm}$ to $1.4 \mathrm{~mm}$, which is specified in the product declaration and shown in Figure 3. The porosity of the 
Brkić, M., Srzić, V.

Modeling of seawater intrusion into coastal aquifers in laboratory conditions

material is $39.6 \%$, and it was calculated using the specific gravity of $2.5 \mathrm{~kg} / \mathrm{l}$ and the bulk density for this fraction of $1.51 \mathrm{~kg} / \mathrm{l}$, which is also stated in the product declaration.

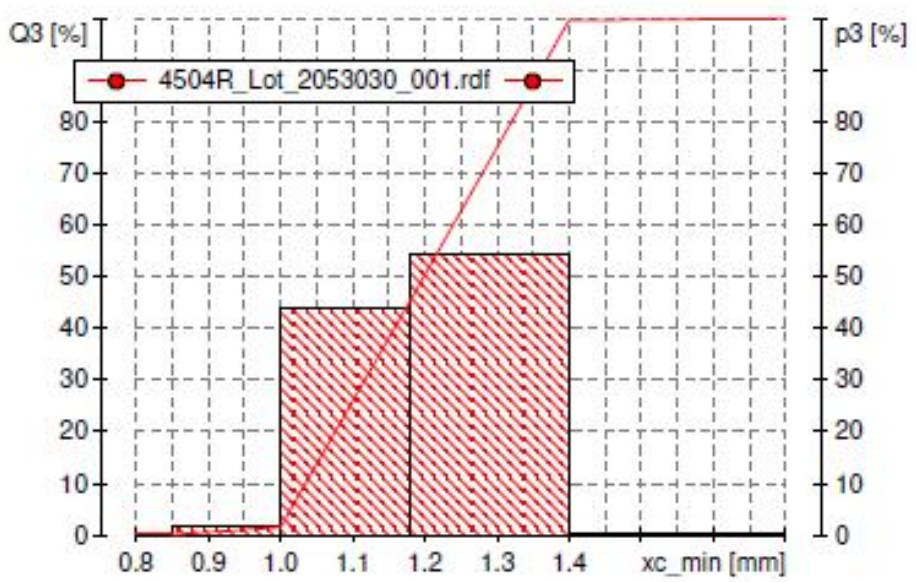

Figure 3. Percentage diagram of different grain diameters (Q3) in the mixture used in the experiment

The porous medium was gradually placed in the chamber to avoid air entrapment in the porous medium. The middle chamber is separated from the other two chambers by a fine screen and geotextile. The geotextile does not allow the infilling to pass from the middle chamber to the other chambers, as shown in Figure 4.

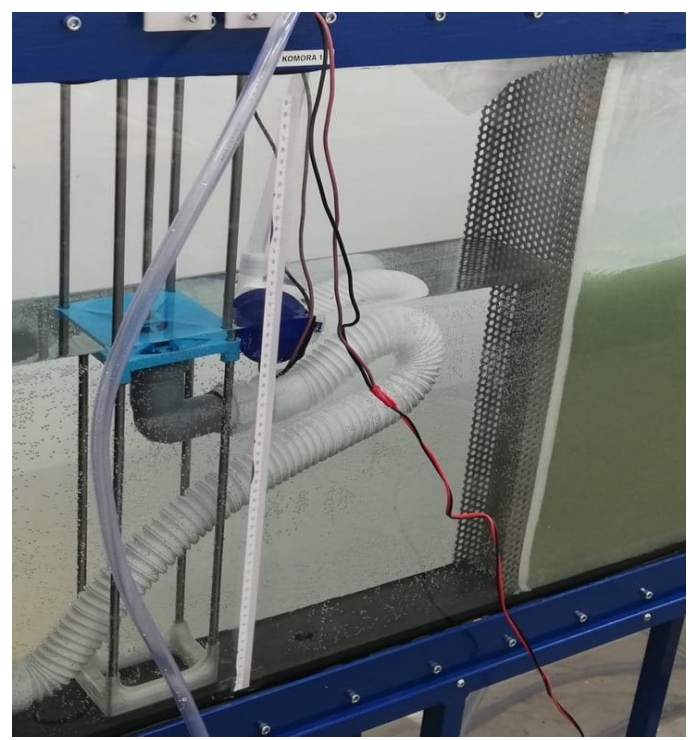

Figure 4. A view of the fine screen wrapped with geotextile

One chamber is filled with fresh water, while the other is filled with salt water. The water level in these two chambers is controlled by overflows that can be moved vertically to the required height using a guide. The overflow system is connected to drainage pipes that remove excess water as shown in Figure 5. 
Brkić, M., Srzić, V.

Modeling of seawater intrusion into coastal aquifers in laboratory conditions

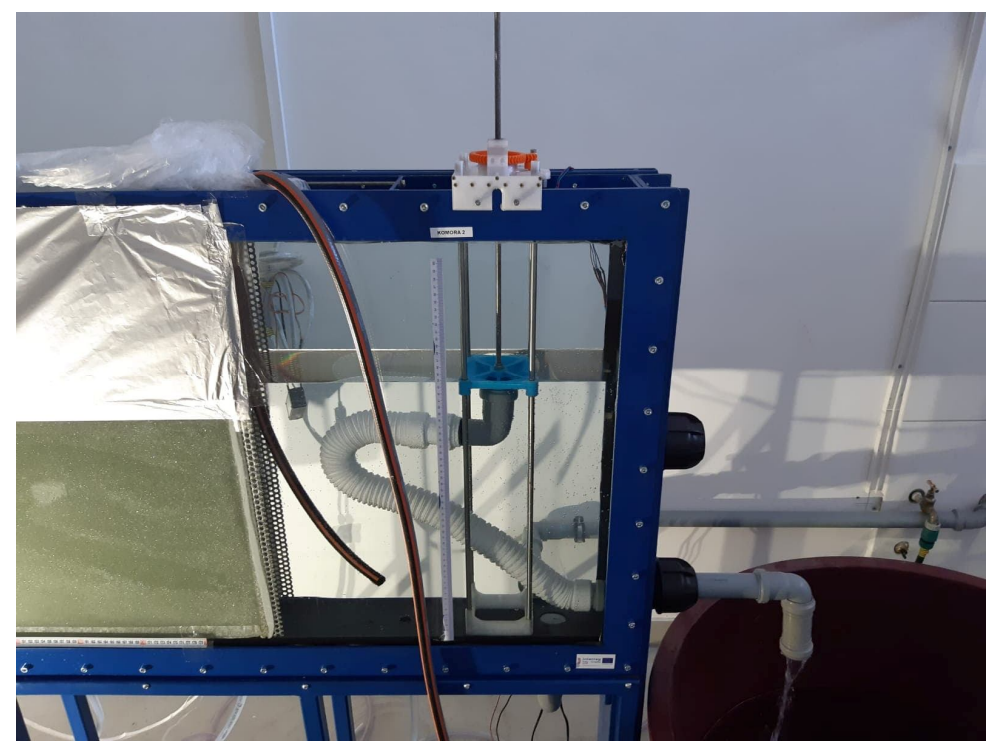

Figure 5. Overflow system connected with inlet and outlet pipes

To make it easier to measure the dimensions of the salt wedge, a tape (marked in $\mathrm{cm}$ and $\mathrm{mm}$ ) is pasted to the bottom and side of the middle chamber. The upper part of the middle chamber with porous medium is covered with aluminum foil to reduce glare in the images. When taking photos, the tank is illuminated with a reflector in order to obtain the clearest images possible. Photographs were taken with a high-resolution GoPro camera every minute in order to obtain a clear movement of the salt wedge through the porous medium as a function of time, as shown in Figure 6.

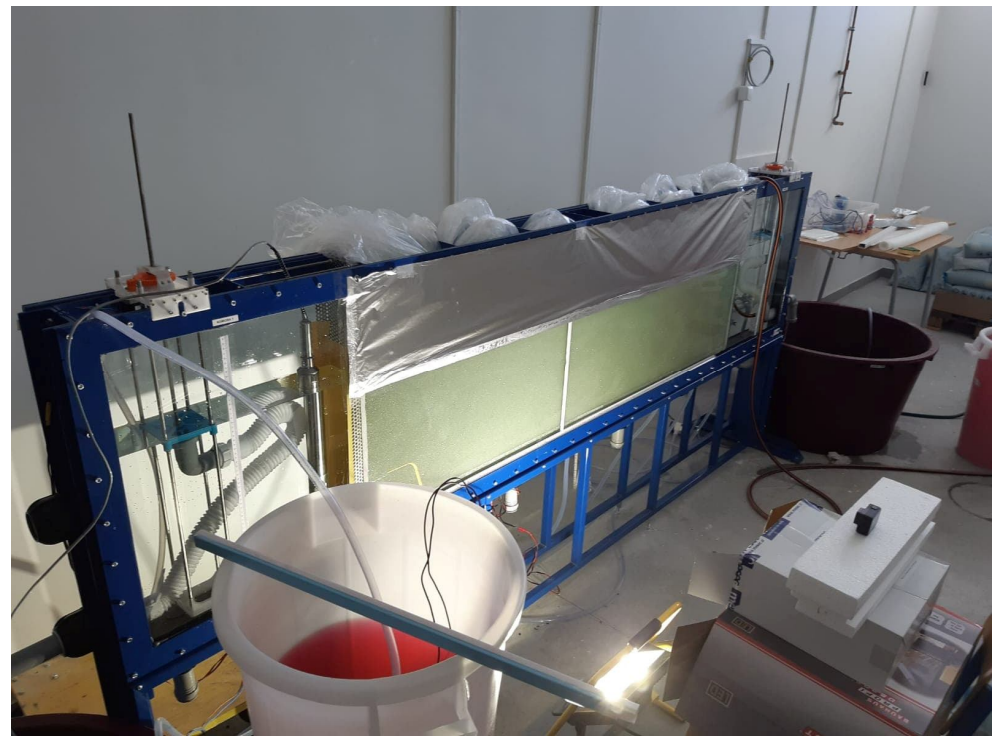

Figure 6. Installed GoPro camera and reflector for recording the intrusion of salt wedge 
Brkić, M., Srzić, V.

Modeling of seawater intrusion into coastal aquifers in laboratory conditions

\section{EXPERIMENTAL PROCESSES AND RESULTS}

\subsection{Darcy's filtration coefficient}

Before the experiment itself, using the outlet on the drainage pipes, Darcy's filtration coefficient of the porous medium was determined based on the previously determined hydraulic gradient. The time required to fill up a test tube with a volume of $600 \mathrm{ml}$ was calculated. The Darcy's filtration coefficient was determined four times for four different hydraulic gradients. The water table levels were determined using overflows attached to the guide. Constant inflow of freshwater in the system is provided through a pipe connected to the water supply. The Darcy's filtration coefficient $(K)$ was calculated using the expression:

$$
Q=K \cdot A \cdot \frac{h_{1}-h_{2}}{l}=-K \cdot A \frac{h_{2}-h_{1}}{l}
$$

where $A$ is the cross-sectional area, $I$ is the length of flow through the sand, and $h_{1}$ and $h_{2}$ are the water heights above the standard parallel plane [19].

For the first determination of the Darcy's filtration coefficient, the upstream water table was set at $53.1 \mathrm{~cm}$, while the downstream water table was set at $42.8 \mathrm{~cm}$ from the bottom of the tank. It took 14.1 seconds to fill up the $600 \mathrm{ml}$ tube, and the Darcy's filtration coefficient of $1.58^{*} 10^{-2} \mathrm{~m} / \mathrm{s}$ was obtained. With each subsequent measurement, the level of the upstream water table was decreased, while the level of the downstream water table remained the same. In the last measurement, the level of the upstream water table was set to $42.8 \mathrm{~cm}$, and it took 52.3 seconds to fill up the test tube, and the Darcy's filtration coefficient of $1.76^{\star} 10^{-2} \mathrm{~m} / \mathrm{s}$ was obtained. Based on four consecutive measurements, the average Darcy's filtration coefficient of $1.67^{*} 10^{-2} \mathrm{~m} / \mathrm{s}$ was obtained in the horizontal direction using Darcy's law. A diagram of the dependence of the filtration rate $(\mathrm{v})$ on the change of hydraulic gradient is shown in Figure 7.

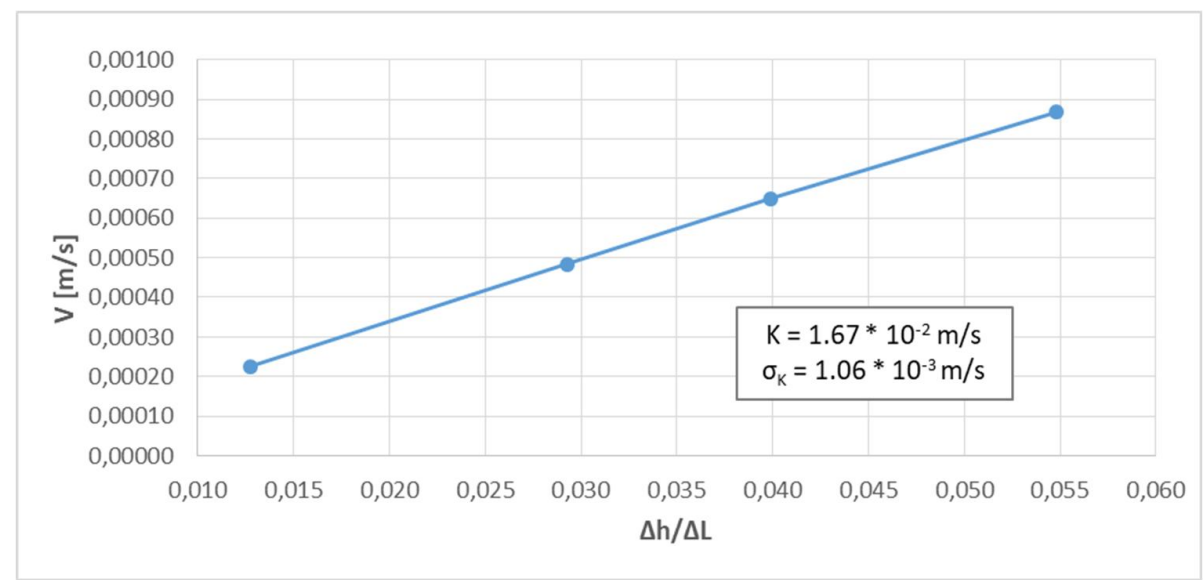

Figure 7. Diagram of the dependence of the infiltration rate $(v)$ on the gradient $(\Delta \mathrm{h} / \Delta \mathrm{L})$ 
Brkić, M., Srzić, V.

Modeling of seawater intrusion into coastal aquifers in laboratory conditions

\subsection{Simulation of seawater intrusion in the coastal aquifer}

\subsubsection{Boundary conditions for flow}

At the beginning of the experiment itself, both chambers were filled with freshwater from the upper side of the tank. Freshwater was supplied to the tank at a constant rate from the water supply pipe. The level of water table in the freshwater chamber was set at $43.35 \mathrm{~cm}$ measured from the bottom of the chamber. The freshwater level in the chamber with assumed salt water was set at $42.20 \mathrm{~cm}$ measured from the bottom of the chamber, as shown in Figures 8 and 9. The steady state was maintained by a constant supply and drainage of water using the drainage system shown in Figure 5.

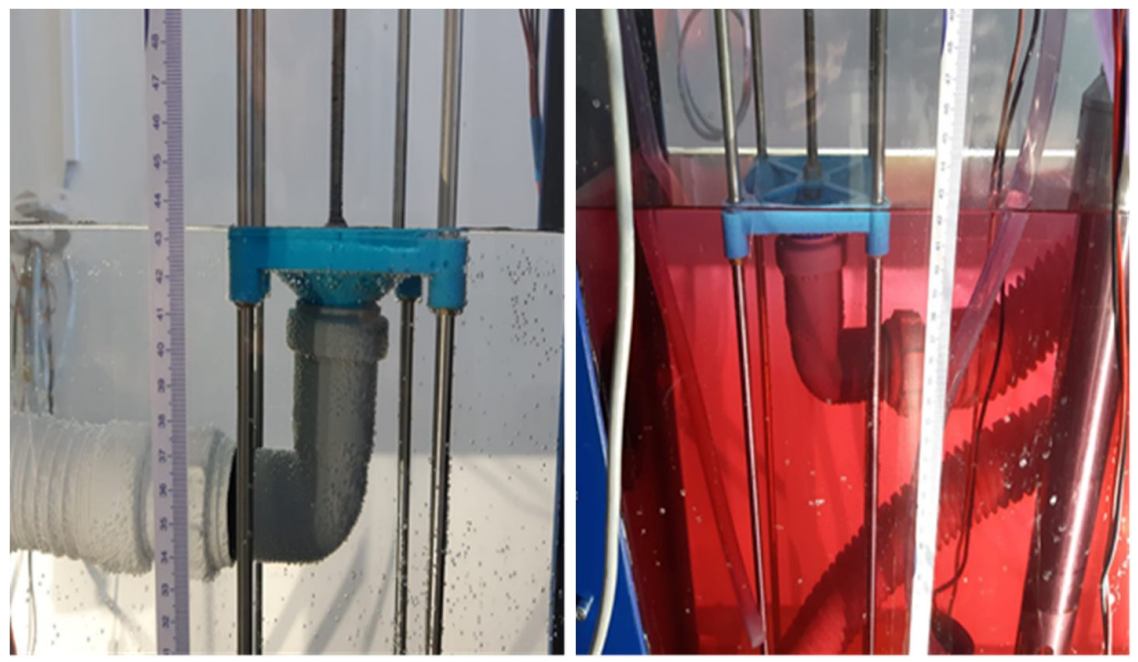

Figures 8 and 9. View of the level of water tables in the chamber with salt and fresh water

\subsubsection{Boundary conditions for intrusion}

One of the preparation activities is to make saltwater from freshwater. Saltwater and freshwater differ in many parameters. The density of freshwater is about $1000 \mathrm{~g} / \mathrm{l}$, while the density of saltwater is about $1025 \mathrm{~g} / \mathrm{l}$. The addition of salt increases the electrical conductivity and density of the solution. Seawater contains about $36 \mathrm{~g} / \mathrm{l}$ of salt, while fresh water contains $0 \mathrm{~g} / \mathrm{l}$ of salt. The electrical conductivity of seawater is about $55 \mathrm{mS} / \mathrm{cm}$, while the electrical conductivity of fresh water is about $200-800 \mu \mathrm{S} / \mathrm{cm}$.

\subsubsection{Preparation of the solution for simulation}

The saltwater was made in two barrels with a volume of $50 \mathrm{I}$ and $60 \mathrm{I}$. Commercial salt was gradually mixed with freshwater until the saltwater characteristics were obtained as shown in Figure 10. 
Brkić, M., Srzić, V.

Modeling of seawater intrusion into coastal aquifers in laboratory conditions

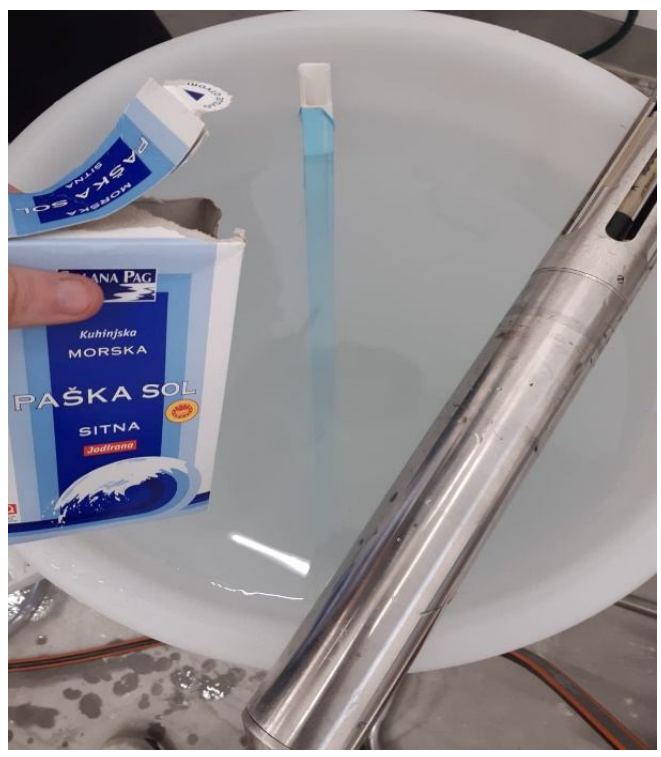

Figure 10. Mixing saltwater with freshwater

About $36 \mathrm{~g}$ of sea salt per one liter of freshwater was gradually added. The goal was to obtain the saltwater density of $1025 \mathrm{~g} / \mathrm{l}$, and salinity of about $36 \mathrm{~g} / \mathrm{l}$. Red food dye Dr. Oetker was used to distinguish freshwater from saltwater. About $76 \mathrm{ml}$ of dye was added to each barrel, and the composition of both barrels was mixed to obtain a homogenized content. The properties of the salt liquid were measured all the time using a Seba hydrometer, which is shown in Figure 11.

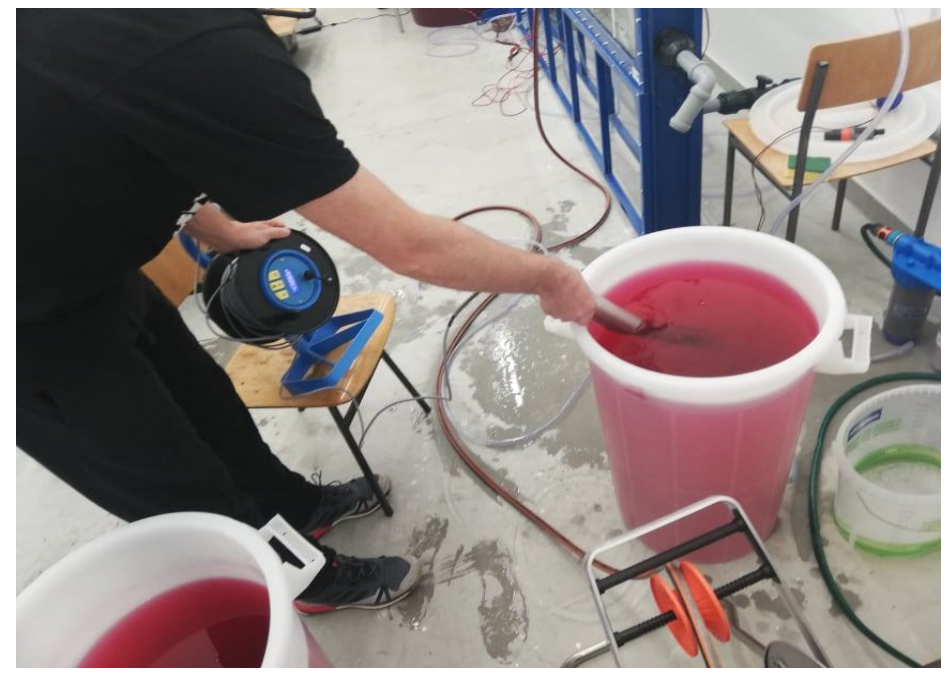

Figure 11. Checking the parameters of colored saltwater 
Brkić, M., Srzić, V.

Modeling of seawater intrusion into coastal aquifers in laboratory conditions

\subsubsection{Monitoring of the experiment}

As satisfactory saltwater parameters were obtained, pumps were used to pump saltwater into the saltwater tank. A constant inflow of saltwater into the chamber is provided by a pump with a capacity of $25 \mathrm{l} / \mathrm{min}$.

Two pumps were used. One pump pumped water from the barrel into the saltwater chamber, and the other pump returned water from the chamber to the barrel. This procedure ensured the circulation of the same saltwater, so that 110 liters of saltwater inside the two barrels was enough to carry out the experiment, as shown in Figure 12.

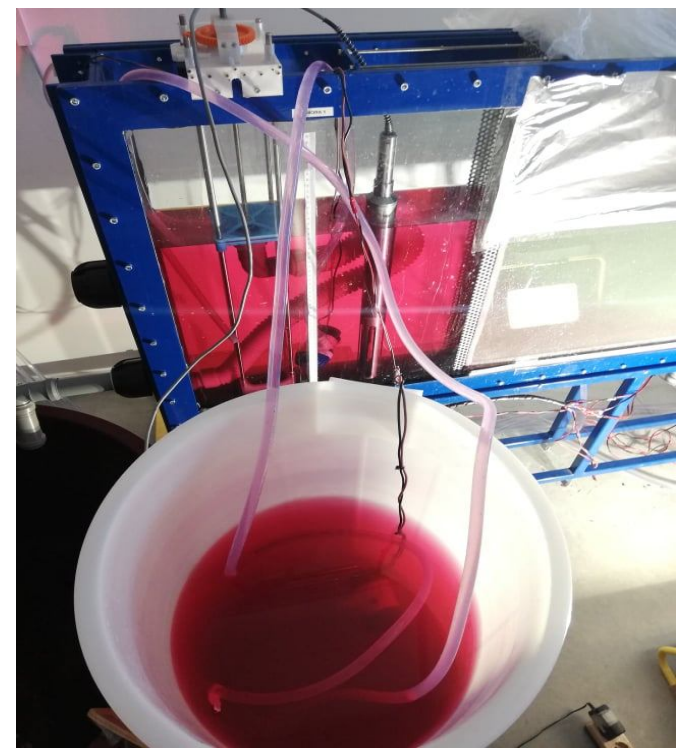

Figure 12. Circulation of saltwater using two pumps

The constant water table levels in both chambers were kept constant by a system of drainage pipes that drained excess water. The difference in water tables is $1.15 \mathrm{~cm}$. This hydraulic gradient caused a constant flow of water towards the saltwater chamber. After the flow stabilized, intrusion of water into the saltwater chamber was prevented by adhesive tape. Saltwater dyed with red color was pumped into the chamber by a system of pumps, while the excess freshwater was removed from the chamber by drainage pipes. This procedure was performed until parameters corresponding to saltwater were obtained in the chamber. The parameters were measured with a Seba hydrometer as shown in Figures 13 and 14. After satisfactory saltwater parameters were obtained, the adhesive tape was quickly removed so that the saltwater chamber was again connected with the rest of the system, and saltwater was allowed to intrude into the middle chamber with the porous medium. The intrusion of saltwater (wedge) was automatically recorded using a GoPro camera every minute. Monitoring and photographing of the intrusion lasted 100 minutes. 

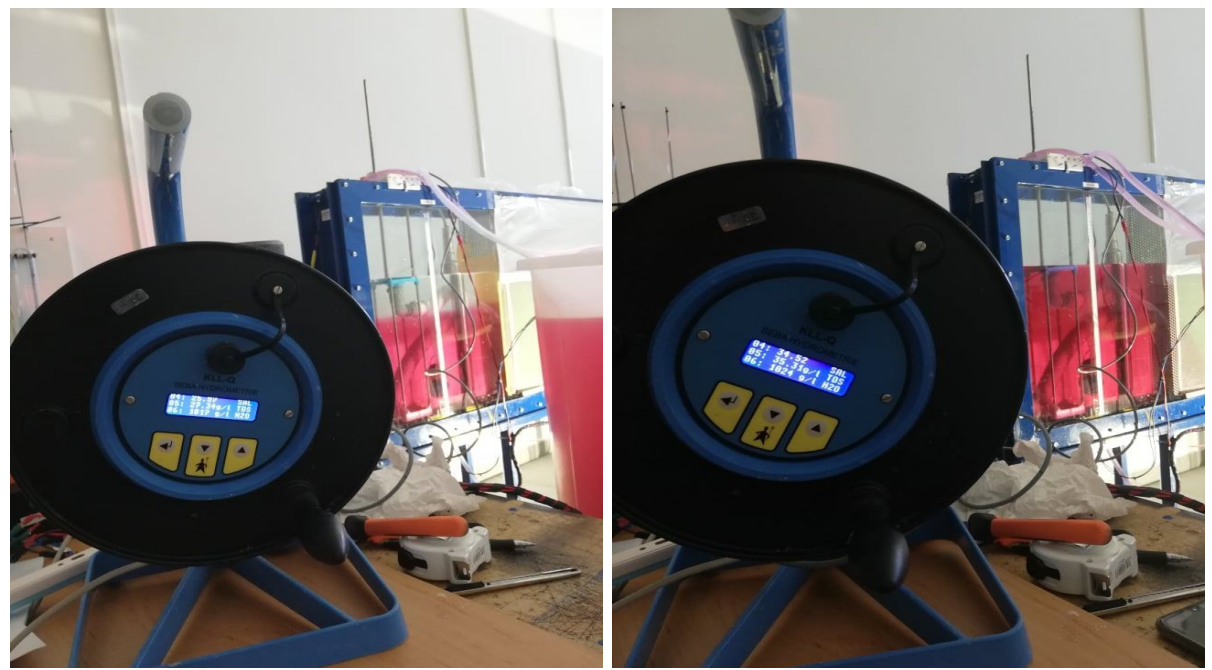

Figures 13 and 14. Adding dyed saltwater to the tank and calculating its parameters

\subsubsection{Results of the experiment}

After removing the adhesive tape, the intrusion of saltwater into the porous medium began due to the difference in density. The saltwater wedge intrusion progressed over time. The images show a sharp transition boundary between the salt wedge and freshwater. The sharp transition boundary is visible through the narrow area of color variation in the transition area. The color is lighter in the transition area. The results show that the mixing zone does not exceed $1 \mathrm{~cm}$. The freshwater moved vertically along the saltwater wedge and entered the saltwater chamber, in which process the freshwater exited the chamber through the drainage system due to the difference in densities. During the advancement of the wedge, a transition from the linear shape to the parabolic shape of the wedge was observed, from which it is evident that the angle between the wedge and the bottom of the aquifer gradual decreases. The wedge initially moved rapidly, while after 90 minutes of recording it significantly slowed down its movement, approaching a steady-state condition, which is shown in Figures 15-22.
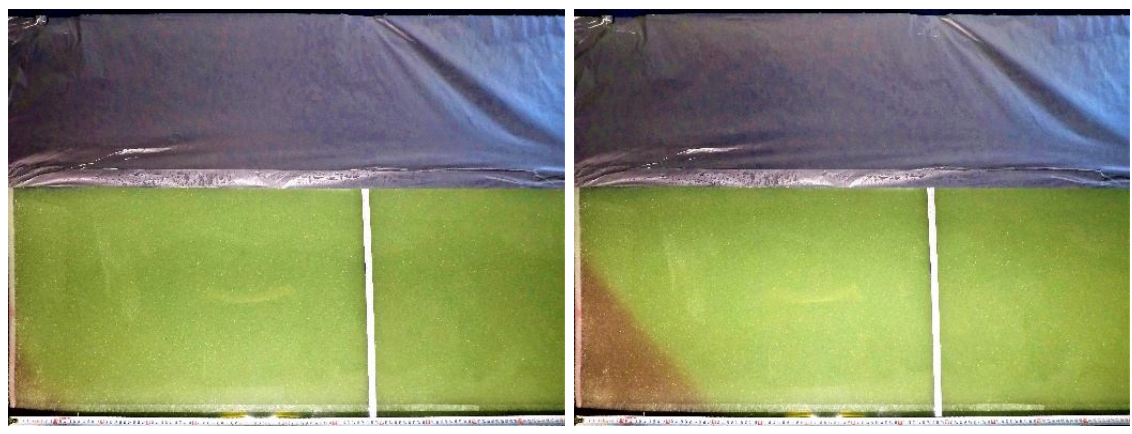

Figures 15 and 16. Saltwater wedge intrusion in the first minute and after 15 minutes 
Brkić, M., Srzić, V.

Modeling of seawater intrusion into coastal aquifers in laboratory conditions
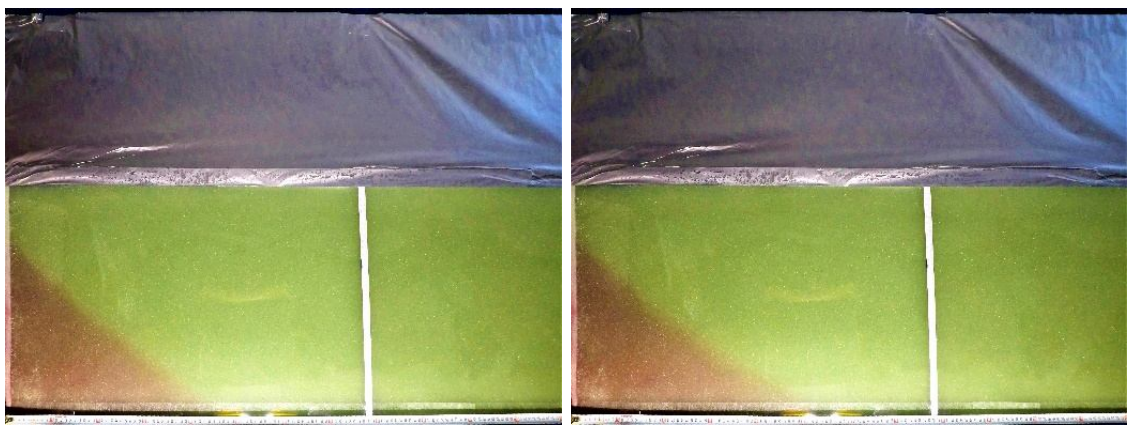

Figures 17 and 18. Saltwater wedge intrusion after 30 and 45 minutes
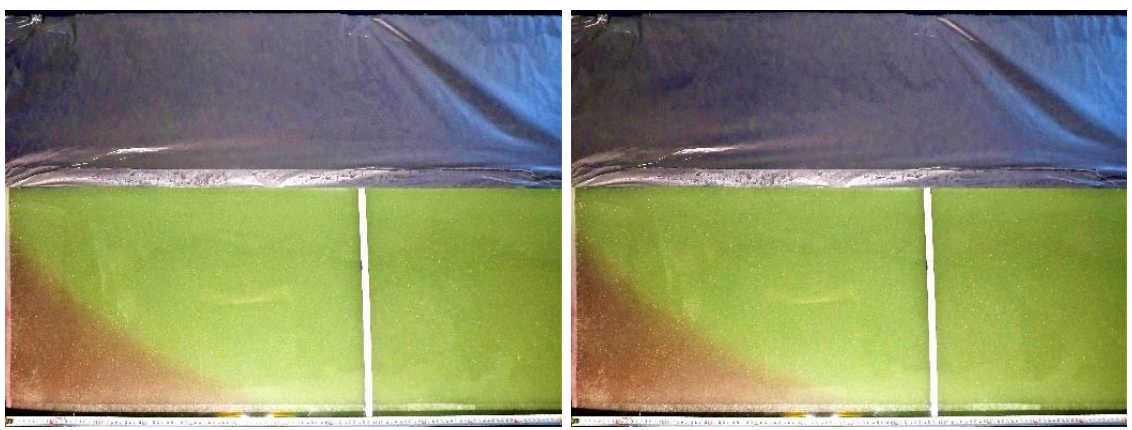

Figures 19 and 20. Saltwater wedge intrusion after 60 and 75 minutes
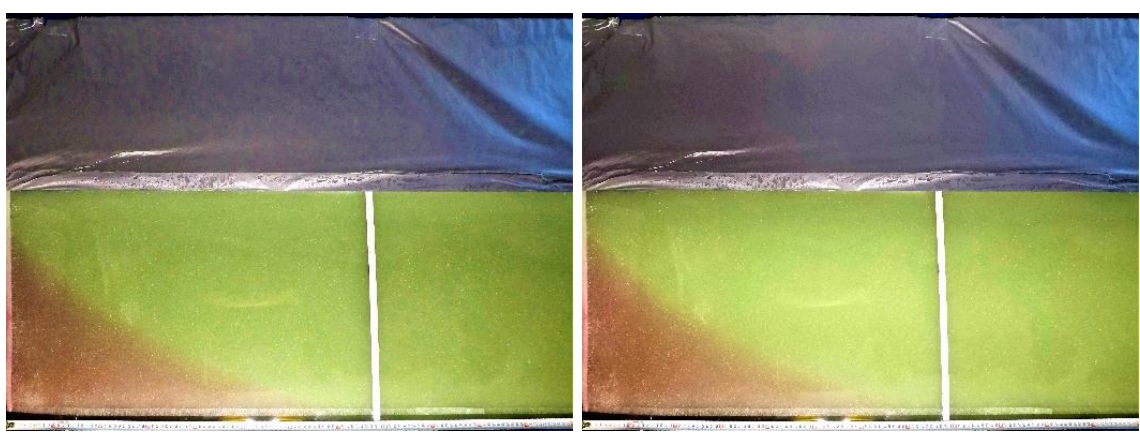

Figures 21 and 22. Saltwater wedge intrusion after 90 and 100 minutes

Figures 15 and 16 show a rapid movement of the salt wedge where the length of the wedge is $32 \mathrm{~cm}$ in the horizontal direction, and $28 \mathrm{~cm}$ in the vertical direction during the first 15 minutes of measurements, which is the fastest movement during 15 minutes of measurements. The linear shape of the wedge is visible here. During the experiment, the wedge intrusion is increasingly slower. Figure 17 shows the wedge dimensions of $46 \mathrm{~cm}$ in the horizontal direction and $30 \mathrm{~cm}$ in the vertical direction after 30 minutes of measurements, and the linear shape of the wedge is still maintained. Figures 19 and 20 show a decrease in wedge intrusion rate, and between the 60th and 75th minute of measurements, elongation of the wedge in the horizontal direction from $64 \mathrm{~cm}$ to $71 \mathrm{~cm}$, and in the vertical direction from $33 \mathrm{~cm}$ to $33.5 \mathrm{~cm}$, is visible. Figures 19 and 20 show a clear transition of wedge shape from linear to parabolic. Figures 21 and 22 show the minimum movement of the wedge, and the wedge increases by $2 \mathrm{~cm}$ in the horizontal direction compared to the previous figure, and in

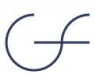


Brkić, M., Srzić, V.

Modeling of seawater intrusion into coastal aquifers in laboratory conditions

the vertical direction the wedge increase is negligible. The final length of the wedge in the horizontal direction is $80 \mathrm{~cm}$, while the final vertical height of the wedge is $33.5 \mathrm{~cm}$. A narrow freshwater-saltwater mixing zone is visible throughout the duration of the experiment.

\section{DISCUSSION}

An experiment to simulate seawater intrusion in a porous coastal aquifer was performed, in which process knowledge was obtained on the dynamics of salt wedge intrusion in a porous medium. The saltwater wedge was obtained for one type of porous medium and with a constant hydraulic gradient that was maintained by a system of drainage pipes. The filtration coefficient for the given state in the experiment was calculated before the experiment using Darcy's law.

The dimensions and behavior of the wedge itself depend on many factors. This experiment was conducted using one porous medium of a certain porosity and the same hydraulic gradient (the levels of water tables in the chambers with freshwater and saltwater were not changed). In further research, it is recommended to use porous media of other diameters (other porosities), and to use several layers of different properties in a single experiment. These changes would influence the coefficient of permeability, which would directly affect the salt wedge intrusion. In further research, it is advisable to use another hydraulic gradient or even change the gradient during the experiment itself, and this would show the reaction of the salt wedge during the changes of water table. In this experiment, saltwater was used in ideal conditions with an average density of $1025 \mathrm{~g} / \mathrm{l}$, and in future experiments it is recommended to test the behavior of saltwater wedge in a thinner or denser saltwater solution than the standard value.

\section{CONCLUSION}

An experiment was conducted to simulate seawater intrusion into a porous coastal aquifer. As evident in Figures 15-22, the intrusion of saltwater into the porous medium is visible due to the difference in the density of saltwater and freshwater. The salt wedge has the maximum force of intrusion into the porous medium at the very beginning. As the wedge approaches the steady-state condition, the changes in shape of the wedge itself are more insignificant. The conditions in the laboratory did not provide an opportunity to monitor the state of the wedge until the actual state of equilibrium that would be achieved in more than 100 minutes of measurements. The final length of the wedge in the horizontal direction was $80 \mathrm{~cm}$, while the height of the wedge was $33.5 \mathrm{~cm}$ after 100 minutes of measurements. The experiment showed that the saltwater-freshwater mixing zone is narrow, and that the freshwater moves along the edge of the wedge and exits the middle chamber. Freshwater from the middle chamber enters the saltwater chamber, where due to the difference in density it separates to the top of the chamber, and is extracted from the chamber by a system of drainage pipes. A transition from the linear shape to the parabolic shape of the wedge is observed during the experiment. After four consecutive measurements, the average filtration coefficient was calculated, and the filtration coefficient was $1.67^{*} 10^{-2} \mathrm{~m} / \mathrm{s}$.

The results of this experiment will help in future planning to solve the problem of saltwater intrusion into coastal aquifers. 
Brkić, M., Srzić, V.

Modeling of seawater intrusion into coastal aquifers in laboratory conditions

\section{REFERENCES}

1. Bear, J., Cheng, A.H.-D., Seawater intrusion in coastal aquifers - concepts, methods and practices. In: Bear, J., Cheng, A.H.-D., Sorek, S., Ouazar, D., Herrera: I. (Eds.), Theory and Applications of Transport in Porous Media, vol. 14, Kluwer Academic Publishers, Dordrecht, 1999.

2. Xue, Y.Q., Wu, J.C., Xie, C.H., Zhang, Y.X., Research of seawater and salt water intrusion of Laizhou Bay, Chinese Science Bulletin, pp. 2360-2368, Nanjing University, Nanjing, 1997.

3. Han, D., Kohfahl, C., Song, X., Xiao, G., Yang, J., Geochemical and isotopic evidence for palaeo-seawater intrusion into the south coast aquifer of Laizhou Bay, Applied Geochemistry, Beijing, 2011.

4. U.S. Geological Survey (USGS), Groundwater resources for the future-Atlantic Coastal Zone, Fact Sheet 085-00, Reston, VA, 2000.

5. Moreno-Gonzales, R., Rodriguez-Mozaz, S., Gros, M., Barcelo, D., Leon, V.M., Seasonal distribution of pharmaceuticals in marine water and sediment from a Mediterranean coastal lagoon (SE Spain), pp. 326-344, Murcia, 2015.

6. Guo, Q.N., Huang, J.W., Zhou, Z.F., Wang, J.G., Experiment and numerical simulation of seawater intrusion under the influences of tidal fluctuation and groundwater exploitation in coastal multilayered aquifers, Geofluids, Nanjing, 2019.

7. Henry, H.R., Salt intrusion into coastal aquifers, Ph.D. thesis, Columbia University, New York, 1960.

8. Croucher, A.E., O'Sullivan, The Henry problem for saltwater intrusion, Water Resour. Res. 31, Auckland, 1995.

9. Ketabchi, H., Mahmoodzadeh, D., Ataie-Ashtiani, B., Werner, A.D., Simmons, C.T., Sealevel rise impact on fresh groundwater lenses in two-layer small islands, Hydrological Processes, pp. 5938-5953, Tehran, 2014.

10. Shi, W.L., Lu, C.H., Ye, Y., Wu, J.C., Li, L., Luo, J., Assessment of the impact of sealevel rise on steady-state seawater intrusion in a layered coastal aquifer, Journal of Hydrology, 563, pp. 851-862, Nanjing, 2018.

11. Guo, Q., Zhang, Y., Zhou, Z., Zhao, Y., Saltwater transport under the influence of sealevel rise in coastal multilayered aquifers, Journal of Coastal Research, Coconut Creek, Florida, 2020.

12. Abd-Elhamid, H.F., Javadi, A.A., A density-dependant finite element model for analysis of saltwater intrusion in coastal aquifers, Journal of Hydrology, pp. 259-271, Exeter, 2011.

13. Mehdizahed, S.S., Karamalipour, S.E., Asoodeh, R., Sea level rise effect on seawater intrusion into layered coastal aquifers (simulation using dispersive and sharp-interface approaches), Ocean Coastal Manag, pp. 11-18, 2017.

14. Sun, D.M., Niu, S.X., Zang, Y.G., Impacts of inland boundary conditions on modeling seawater intrusion in coastal aquifers due to sea-level rise, Natural Hazards, pp. 1-19, 2017.

15. Sefelnasr, A., Sherif, M., Impacts of seawater rise on seawater intrusion in the Nile Delta aquifer, Ground Water, 52(2), pp. 264-276, Assuit, 2014.

16. Goswami, R.R., Clement, T.P., Laboratory-scale investigation of saltwater intrusion dynamics, Water Resourc. Res. 43, Auburn, 2007.

17. Kuan, W.K., Jin, G., Xin, P. et al., Tidal influence on seawater intrusion in unconfined coastal aquifers, Water Resourc. Res. 48, pp. 136-149., Queensland, 2012.

18. Na, J., Chi, B., Zhang, Y., Li, J., Jiang, X, Study on the influence of seawater density variation on sea water intrusion in confined coastal aquifers, Springer-Verlag GmbH, 2019. 19. Urumović, K., Fizikalne osnove dinamike podzemnih voda (Physical Principles of Groundwater Dynamics), Faculty of Mining, Geology and Petroleum Engineering, University of Zagreb, Zagreb, 2003. 